\title{
Postharvest Storage Losses Associated with Rhizomania in Sugar Beet
}

\author{
L. G. Campbell and K. L. Klotz, United States Department of Agriculture-Agricultural Research Service, Northern \\ Crop Science Laboratory, Fargo, ND 58105-5677, and L. J. Smith, Northwest Research and Outreach Center, Uni- \\ versity of Minnesota, Crookston 56716
}

\begin{abstract}
Campbell, L. G., Klotz, K. L., and Smith, L. J. 2008. Postharvest storage losses associated with rhizomania in sugar beet. Plant Dis. 92:575-580.

During storage of sugar beet, respiration and rots consume sucrose and produce invert sugar. Diseases that occur in the field can affect the magnitude of these losses. This research examines the storage of roots with rhizomania (caused by Beet necrotic yellow vein virus) and the effectiveness of rhizomania-resistant hybrids in reducing postharvest losses. Roots of susceptible hybrids from sites with rhizomania had respiration rates 30 days after harvest (DAH) that ranged from 0.68 to $2.79 \mathrm{mg}$ of $\mathrm{CO}_{2} \mathrm{~kg}^{-1} \mathrm{~h}^{-1}$ higher than roots of the resistant hybrids. This difference ranged from 2.60 to $13.88 \mathrm{mg}$ of $\mathrm{CO}_{2} \mathrm{~kg}^{-1} \mathrm{~h}^{-1} 120 \mathrm{DAH}$. Roots of resistant hybrids from sites with rhizomania had $18 \mathrm{~kg}$ more sucrose per ton than roots from susceptible hybrids $30 \mathrm{DAH}$, with this difference increasing to $55 \mathrm{~kg} \mathrm{Mg}^{-1} 120 \mathrm{DAH}$. The invert sugar concentration of susceptible hybrids from sites with rhizomania ranged from 8.38 to $287 \mathrm{~g}$ per $100 \mathrm{~g}$ of sucrose higher than that for resistant hybrids $120 \mathrm{DAH}$. In contrast, differences between susceptible and resistant hybrids in respiration rate, sucrose loss, and invert sugar concentration in the absence of rhizomania were relatively small. Storage losses due to rhizomania can be minimized by planting resistant hybrids and processing roots from fields with rhizomania soon after harvest.
\end{abstract}

Additional keywords: Beta vulgaris L., BNYVV, long-term storage

In the upper Midwest of the United States, up to 15 million tons of sugar beet (Beta vulgaris L.) are stored in large exposed piles for up to 200 days prior to processing. During storage, respiration, rotting, invert sugar accumulation, and physical deterioration decrease the extractable sucrose concentration of the roots. Invert sugars are converted to organic acids which decrease processing efficiency, increase the proportion of sucrose retained in molasses, and contribute to color formation in the sugar produced (10). Much of the storage research conducted to date has focused on minimizing deterioration by modifying harvest and piling operations and conditions within the piles (3); however, crop condition at harvest $(1,5)$, including diseases that occurred during the growing season $(4,11,16)$, may affect sub-

Corresponding author: L. G. Campbell

E-mail: larry.campbell@ars.usda.gov

Trade, firm, or corporate names are mentioned only to disclose information that may be of interest to the reader. Such use does not constitute an endorsement or approval by the Agricultural Research Service of any product to the exclusion of others that may be equally suitable or superior.

Accepted for publication 7 November 2007.

doi:10.1094/PDIS-92-4-0575

This article is in the public domain and not copyrightable. It may be freely reprinted with customary crediting of the source. The American Phytopathological Society, 2008. sequent storage losses. Unfortunately, the meager information on the consequences of storing diseased roots prevents informed decisions by processors attempting to minimize storage losses.

Rhizomania (caused by Beet necrotic yellow vein virus [BNYVV]) was positively identified in southern Minnesota in 1996 (15). Since then, the disease has become a serious threat to sugar beet production throughout Minnesota and eastern North Dakota. Because of its persistence in the soil and the absence of other economical control methods (9), rhizomania is managed primarily by growing resistant hybrids $(7,15)$. The rapid spread of the disease required seed companies to respond quickly and, in many cases, it was necessary to compromise yield, quality, or adaptation to meet the demand for rhizomania-resistant hybrids. Growers were faced with a choice of reduced yield if they planted a susceptible hybrid and the disease appeared or slight reductions in yield and quality if the disease did not materialize and they had planted a resistant hybrid. Some seed companies attempted to resolve this dilemma by providing triploid hybrids that had intermediate levels of rhizomania resistance, quality, and yield potential. The resistant hybrids were diploids resulting from a cross between a resistant female $\left(R z_{1} R z_{1}\right)$ and a susceptible $\left(r z_{1} r z_{1}\right)$ diploid pollinator. Triploid hybrids were produced by crossing a resistant diploid female $\left(R z_{I}\right.$ $\left.R z_{1}\right)$ and a rhizomania susceptible tetraploid pollinator $\left(\begin{array}{llllll}r z_{1} & r z_{1} & r z_{1} & r z_{1}\end{array}\right)$. The triploid hybrids lacked the high level of resistance exhibited by the resistant diploid hybrids but generally were more productive in the absence of rhizomania.

As the prevalence of BNYVV increased, questions regarding the storage of roots with rhizomania also increased. The objective of this study was to obtain information on the effects of rhizomania on postharvest storability of sugar beet. This information is intended to assist growers and agriculturalists in determining the value of rhizomania-resistant hybrids and processors in deciding if roots from fields with rhizomania should be piled separately and processed early in the processing campaign or if special handling is unnecessary.

\section{MATERIALS AND METHODS}

Roots of rhizomania-resistant and rhizomania-susceptible commercial sugar beet hybrids from four environments with rhizomania and five environments with no rhizomania were used to assess the impact of rhizomania on postharvest respiration rate, invert sugar accumulation, and sucrose losses during storage. The four environments with rhizomania were Eldred and Crookston, $\mathrm{MN}$ in 2002; Crookston, MN in 2004; and Climax, $\mathrm{MN}$ in 2005. At these sites, leaves of the rhizomaniasusceptible hybrids exhibited the characteristic upright posture and yellow color associated with rhizomania. Roots of the susceptible hybrids were stunted, constricted below the soil surface, and had numerous small lateral roots. Resistant hybrids had normal green leaves and typical well-developed roots. Symptoms of the hybrids with intermediate resistance (triploid hybrids) were less pronounced than those of the susceptible hybrids. The rhizomania-free environments were Fargo and Saint Thomas, ND in 2003; Stephen, $\mathrm{MN}$ in 2004; and the Northwest Research and Outreach Center (NWROC) north of Crookston, MN in 2005 and 2006. The rhizomania-free sites were selected because they had no apparent complicating diseases and included both resistant and susceptible hybrids.

Only three hybrids were available for the 2002 and 2003 trials: American Crystal 999 (ACH-999, rhizomania susceptible), Beta 4811 (B-4811, resistant), and Beta 4818 (B-4818, intermediate resistance). The 2004 trials included two susceptible hybrids, American Crystal 820 (ACH-820) and Beta 3800 (B-3800); four resistant hybrids, Beta 1305 (B-1305), Hilleshog 
2463 (H-2463), Hilleshog 2469 (H-2469), and Vanderhave 46177 (V-46177); and one hybrid with intermediate resistance, B4818. One susceptible, ACH-820; one intermediate, American Crystal 308 (ACH803); and four resistant hybrids, B-1305, Hilleshog 2467 (H-2467), Holly 317 (HH317), and Seedex Prizm (Prizm) were available from the Climax, $\mathrm{MN}$ site in 2005. The NWROC 2005 and 2006 trials provided additional comparisons of resistant and susceptible hybrids in environments without rhizomania.

At all sites, except NWROC 2005 and 2006, the hybrids were arranged in a randomized complete block design with two replications. Three 24-root samples of each hybrid were obtained from each replicate. The hybrids were arranged in a randomized complete block design with three replications at NWROC in 2005 and 2006 and a single 24-root sample was obtained from each experimental unit. Standard agronomic practices, which included herbicide applications for weed control and foliar fungicide applications for Cercospora leaf spot (caused by Cercospora beticola Sacc.) control, were used at all sites. A combined analysis of variance was performed when environments had the same hybrids and replication. Environments (location-year combinations) were assumed to be random and hybrids were considered fixed effects for the combined analysis of variance (13). Means were compared using Fisher's protected least significant difference with $\alpha=0.10$ (6). The "Estimate" function of the SAS GLM procedure (SAS 9.1; SAS Institute, Inc., Cary, NC) was used to estimate the difference between the average of the rhizomania-resistant hybrids and the average of the susceptible hybrids in each environment (12); hybrids with intermediate resistance were not included in these calculations.

Harvested roots were transported promptly to Fargo, ND, washed, and placed in perforated plastic produce bags. Roots then were placed on shelves in a room maintained at $4.5^{\circ} \mathrm{C}$ and 90 to $95 \%$ relative humidity. Respiration rate was measured 30, 60, and 120 days after harvest (DAH). Extractable sucrose concentration and invert sugar concentrations were measured on half of the roots (12 roots) in each sample $30 \mathrm{DAH}$ and on the remaining roots $120 \mathrm{DAH}$.

Respiration rate was determined by placing a 12-root sample in a 23-liter sealed bucket equipped with inlet and outlet tubes through which ambient air was continuously pumped at a flow rate of 475 $\mathrm{ml} \mathrm{min}{ }^{-1}$. After $24 \mathrm{~h}$, the $\mathrm{CO}_{2}$ concentration of the air from the exit tube was determined with an infrared $\mathrm{CO}_{2}$ analyzer (Licor LI-6252, Lincoln, NE). The $\mathrm{CO}_{2}$ concentration of ambient air from the exit tube of an empty bucket was subtracted from this measurement and the respiration rate expressed as milligrams of $\mathrm{CO}_{2}$ produced per kilogram of roots per hour (2).

Sucrose concentration and purity were used to calculate extractable sucrose concentration (8). Extractable sucrose is that portion of the total sucrose in the root that can be extracted using standard sugar factory operations, expressed as kilograms of sucrose per megagrams of roots. Sucrose was determined polarimetrically (14). Purity (sucrose as a percentage of dry substance) was determined using the procedures described by Dexter et al. (8). Twenty-gram brei (fine beet particles - the product of a beet saw) samples were oven dried at $80^{\circ} \mathrm{C}$ to determine dry matter concentration. Extractable sucrose concentrations for the 30-DAH samples were expressed on a fresh weight basis. Concentrations for the 120-DAH samples were adjusted to account for slight changes in dry matter content during storage and expressed on a fresh weight concentration equal to the corresponding sample 30 DAH.

Glucose and fructose concentrations were determined by high-performance liquid chromatography (HPLC) using lactose as an internal standard. Extracts used for polarimetry were diluted 100-fold, passed over a $0.2-\mu \mathrm{m}$ nylon filter, and injected on to a 250-by-4-mm Dionex CarboPack PA-10 column (Sunnyvale, CA) equipped with a 50-by-4-mm CarboPack PA-10 guard column, and eluted isocratically with $60 \mathrm{mM} \mathrm{NaOH}$ and $10 \mathrm{mM}$

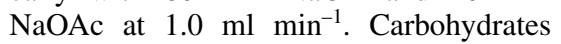
were detected with a Dionex ED50 electrochemical detector operating in pulsed amperometric mode using the manufacturer's recommended settings and quantified using external standards. Invert sugar (glucose + fructose) concentrations are reported as grams per 100 grams of sucrose $(\mathrm{g} / 100 \mathrm{~S})$. Invert sugar analysis of the 2005, 30-DAH samples are not presented because of problems with sample storage.

\section{RESULTS}

In the 2002-03 trials, roots of the rhizomania-susceptible hybrid ACH-999 from the two sites with rhizomania (Eldred and Crookston) had higher 30-DAH respiration rates than roots from the sites without rhizomania (Tables 1 and 2). Furthermore, during the 90 days between sampling dates, the respiration rate of $\mathrm{ACH}-999$ increased to levels that were 3.2 times its 30-DAH respiration rate at Eldred and 1.7 times its 30-DAH respiration rate at Crookston while remaining relatively constant at Fargo and St. Thomas. The 120DAH respiration rate of $\mathrm{ACH}-999$ roots from Eldred and Crookston were 4.3 and 1.9 times the average respiration rate of ACH-999 roots from the two trials without rhizomania. For all three sampling dates, the respiration rate of roots of the rhizomania-resistant hybrid B-4811 from Eldred and Crookston was lower than the corre- sponding respiration rate of $\mathrm{ACH}-999$ at the same site. In contrast, the difference in respiration rates within a location between roots of B-4811 and ACH-999 from Fargo and St. Thomas were small and, with one exception, not significant. The 120-DAH respiration rate of $\mathrm{B}-4811$ roots from Eldred was 2.2 times the average respiration rate of B-4811 from the nonrhizomania sites and 2.2 times the 30-DAH respiration rate. This suggests that severe rhizomania may have had a negative impact on respiration rate of the resistant hybrid similar to, but less than, that observed in the susceptible hybrid ACH-999. The respiration rates of roots of the hybrid with intermediate resistance, B-4818, followed a response pattern similar to that observed for the susceptible hybrid ACH-999 at Eldred and similar to the resistant hybrid B-4811 at Crookston.

Extractable sucrose concentrations 30 DAH ranged from 94 to $161 \mathrm{~kg} \mathrm{Mg}^{-1}$ and from 27 to $143 \mathrm{~kg} \mathrm{Mg}^{-1} 120 \mathrm{DAH}$ in the 2002-03 trials (Tables 1 and 2). At Eldred and Crookston, the extractable sucrose concentration of the rhizomania-resistant hybrid $30 \mathrm{DAH}$ was greater than that of the susceptible hybrid, whereas the extractable sucrose concentration of the susceptible hybrid was equal to or greater than the resistant hybrid at Fargo and St. Thomas. The difference between the resistant and susceptible hybrids is more apparent in comparisons of the 120-DAH extractable sucrose concentrations and the sucrose loss during the 90 days between sampling dates. During this 90 days in storage, the extractable sucrose concentration of $\mathrm{ACH}$ 999 roots from Eldred decreased from 125 to $27 \mathrm{~kg} \mathrm{Mg}^{-1}$, a loss of $77 \%$ of the sucrose available $30 \mathrm{DAH}$. In contrast, $30 \%$ of the sucrose available $30 \mathrm{DAH}$ in roots of ACH-999 from Crookston was lost during storage and only 11 and $14 \%$ losses occurred in roots of this hybrid from St. Thomas and Fargo, respectively. Moreover, small differences among locations for sucrose loss in B-4811 roots appeared to be independent of the presence or absence of rhizomania. Extractable sucrose losses for the hybrid with intermediate resistance, B4818 , followed a pattern similar to that described for respiration rate; losses at Eldred were higher than any other hybridenvironment combination, except ACH999 at Eldred, and losses at Crookston were not substantially different from sucrose losses at St. Thomas and Fargo.

With the exception of the relatively high invert sugar concentration for ACH-999 at Eldred (Table 1), differences in invert sugar concentration 30 DAH were small, suggesting they were influenced by factors other than rhizomania severity or rhizomania resistance of the hybrid. Because invert sugar is produced at the expense of sucrose, the occurrence of high 120-DAH invert sugar concentrations in conjunction with high extractable sugar losses was not 
unexpected. The invert sugar concentration of ACH-999 roots from Eldred (291.67 g/100S) 120 DAH was approximately three times its sucrose concentration. The relative invert sugar concentration of $\mathrm{ACH}-$ 999 roots from Crookston also was high $(71.74 \mathrm{~g} / 100 \mathrm{~S})$ but only one-fourth of that observed at Eldred. Roots of B-4818 from Eldred also had relatively high invert sugar concentration (179.37 g/100S). Invert sugar concentrations of all other hybridenvironment combinations were lower; ranging from 3.98 to $13.06 \mathrm{~g} / 100 \mathrm{~S}$.
In the 2004 trials, a significant hybridlocation interaction (Table 2) for all traits except invert sugar $30 \mathrm{DAH}$ indicated that the relative response of the hybrids depended upon the location in which they were produced (Table 3). A significant hybrid main effect for invert sugar concentration $30 \mathrm{DAH}$ was, in large part, due to the relatively high invert sugar concentration of B-4818 in both the presence and absence of rhizomania. Location main effects were significant only for extractable sucrose concentration 30 and 120
DAH; in both cases, the extractable sucrose concentration of roots from Stephen (rhizomania absent) was higher than the extractable sucrose concentration of roots from Crookston (rhizomania present). At Crookston, the respiration rate of the two rhizomania-susceptible hybrids, ACH- 820 and B-3800, was greater than the respiration rate of any of the resistant hybrids 30 , 60, and 120 DAH. Differences in respiration rate among the hybrids at Stephen did not appear to be related to the hybrids' response to rhizomania. The 120-DAH

Table 1. Respiration rate 30, 60, and 120 days after harvest (DAH) and extractable sucrose and invert sugar concentration of roots of rhizomania-resistant and -susceptible sugar beet hybrids 30 and 120 DAH from locations with (Eldred and Crookston, MN; 2002) and without (St. Thomas and Fargo, ND; 2003) rhizomania $^{\mathrm{x}}$

\begin{tabular}{|c|c|c|c|c|c|c|c|c|c|}
\hline \multirow[b]{2}{*}{ Hybrid, response, loc. ${ }^{y}$} & \multicolumn{3}{|c|}{$\begin{array}{c}\text { Respiration rate } \\
\left(\mathbf{m g} \text { of } \mathrm{CO}_{2} \mathbf{k g}^{-1} \mathbf{h}^{-1}\right)\end{array}$} & \multicolumn{2}{|c|}{$\begin{array}{c}\text { Extractable sucrose } \\
\left(\mathrm{kg} \mathrm{Mg}^{-1}\right)\end{array}$} & \multicolumn{2}{|c|}{$\begin{array}{c}\text { Extractable sucrose loss } \\
30 \text { to } 120 \text { DAH } \\
\end{array}$} & \multicolumn{2}{|c|}{$\begin{array}{c}\text { Invert sugar } \\
\text { (g/100 g of sucrose) }\end{array}$} \\
\hline & 30 DAH & 60 DAH & 120 DAH & 30 DAH & 120 DAH & Weight $^{\mathrm{z}}$ & Percent & 30 DАН & 120 DAH \\
\hline \multicolumn{10}{|l|}{ ACH-999, susceptible } \\
\hline Eldred & $6.10 \mathrm{f}$ & $12.81 \mathrm{~g}$ & $19.66 \mathrm{f}$ & $125 \mathrm{~b}$ & $27 \mathrm{a}$ & $1.09 \mathrm{f}$ & $77 \mathrm{e}$ & $7.29 \mathrm{e}$ & $291.67 \mathrm{~d}$ \\
\hline Crookston & $4.96 \mathrm{f}$ & $5.61 \mathrm{e}$ & $8.52 \mathrm{~d}$ & $131 \mathrm{bc}$ & $91 \mathrm{~d}$ & $0.45 \mathrm{~d}$ & $30 \mathrm{c}$ & $5.26 \mathrm{~d}$ & $71.74 \mathrm{~b}$ \\
\hline St Thomas & $4.18 \mathrm{de}$ & $4.34 \mathrm{~b}-\mathrm{d}$ & $5.36 \mathrm{c}$ & $161 \mathrm{~g}$ & $143 \mathrm{~g}$ & $0.20 \mathrm{a}-\mathrm{c}$ & $11 \mathrm{ab}$ & $1.58 \mathrm{ab}$ & $11.11 \mathrm{a}$ \\
\hline Fargo & $3.63 \mathrm{~b}-\mathrm{d}$ & $3.29 \mathrm{ab}$ & $3.78 \mathrm{a}-\mathrm{c}$ & $101 \mathrm{a}$ & $86 \mathrm{~d}$ & $0.17 \mathrm{a}-\mathrm{c}$ & $14 \mathrm{ab}$ & $4.58 \mathrm{~d}$ & $6.15 \mathrm{a}$ \\
\hline Hybrid mean & 4.72 & 6.51 & 9.33 & 130 & 86 & 0.48 & 33 & 4.67 & 95.17 \\
\hline \multicolumn{10}{|l|}{ B- 4818 , intermediate } \\
\hline Eldred & $4.10 \mathrm{de}$ & $8.74 \mathrm{f}$ & $15.75 \mathrm{e}$ & $132 b-d$ & $53 \mathrm{~b}$ & $0.88 \mathrm{e}$ & $59 \mathrm{~d}$ & $2.84 \mathrm{bc}$ & $179.37 \mathrm{c}$ \\
\hline Crookston & $4.19 \mathrm{de}$ & $4.68 \mathrm{de}$ & $4.91 \mathrm{a}-\mathrm{c}$ & $139 \mathrm{c}-\mathrm{e}$ & $109 \mathrm{e}$ & $0.33 \mathrm{~b}-\mathrm{d}$ & $20 \mathrm{bc}$ & $4.46 \mathrm{~d}$ & $13.06 \mathrm{a}$ \\
\hline St. Thomas & $3.47 \mathrm{bc}$ & $3.74 \mathrm{a}-\mathrm{d}$ & $5.38 \mathrm{c}$ & $152 \mathrm{fg}$ & $139 \mathrm{fg}$ & $0.14 \mathrm{ab}$ & $8 \mathrm{ab}$ & $1.45 \mathrm{a}$ & $7.29 \mathrm{a}$ \\
\hline Fargo & $3.05 \mathrm{ab}$ & $3.52 \mathrm{a}-\mathrm{c}$ & $3.43 \mathrm{ab}$ & $94 \mathrm{a}$ & $65 \mathrm{bc}$ & $0.32 \mathrm{~b}-\mathrm{d}$ & $30 \mathrm{c}$ & $4.14 \mathrm{~cd}$ & $6.73 \mathrm{a}$ \\
\hline Hybrid mean & 3.70 & 5.17 & 7.37 & 129 & 92 & 0.42 & 29 & 3.22 & 51.61 \\
\hline \multicolumn{10}{|l|}{ B-4811, resistant } \\
\hline Eldred & $3.80 \mathrm{c}-\mathrm{e}$ & $4.60 \mathrm{c}-\mathrm{e}$ & $8.41 \mathrm{~d}$ & $151 \mathrm{f}$ & $117 \mathrm{e}$ & $0.37 \mathrm{c}$ & $22 \mathrm{bc}$ & $1.80 \mathrm{ab}$ & $4.95 \mathrm{a}$ \\
\hline Crookston & $4.28 \mathrm{e}$ & $3.85 \mathrm{~b}-\mathrm{d}$ & $4.95 \mathrm{bc}$ & 143 ef & 124 ef & $0.20 \mathrm{a}-\mathrm{c}$ & $12 \mathrm{ab}$ & $4.50 \mathrm{~d}$ & $6.76 \mathrm{a}$ \\
\hline St. Thomas & $4.16 \mathrm{de}$ & $3.96 \mathrm{~b}-\mathrm{d}$ & $4.54 \mathrm{a}-\mathrm{c}$ & $141 \mathrm{de}$ & $137 \mathrm{fg}$ & $0.04 \mathrm{a}$ & $2 \mathrm{a}$ & $1.51 \mathrm{ab}$ & $5.94 \mathrm{a}$ \\
\hline Fargo & $2.60 \mathrm{a}$ & $2.74 \mathrm{a}$ & $3.19 \mathrm{a}$ & $99 \mathrm{a}$ & 79 ac & $0.22 \mathrm{a}-\mathrm{c}$ & $19 \mathrm{bc}$ & $4.03 \mathrm{~cd}$ & $3.98 \mathrm{a}$ \\
\hline Hybrid mean & 3.71 & 3.79 & 5.21 & 134 & 115 & 0.21 & 13 & 2.96 & 5.41 \\
\hline \multicolumn{10}{|l|}{ Location means } \\
\hline Eldred & $4.66 \mathrm{~A}$ & $8.72 \mathrm{~A}$ & $14.52 \mathrm{~A}$ & $136 \mathrm{~B}$ & $66 \mathrm{C}$ & $0.78 \mathrm{~A}$ & $52 \mathrm{~A}$ & $3.98 \mathrm{~A}$ & $158.66 \mathrm{~A}$ \\
\hline Crookston & $4.47 \mathrm{AB}$ & $4.71 \mathrm{~B}$ & $6.13 \mathrm{~B}$ & $138 \mathrm{~B}$ & $108 \mathrm{~B}$ & $0.33 \mathrm{~B}$ & $21 \mathrm{~B}$ & $4.73 \mathrm{~A}$ & 30.52 B \\
\hline St. Thomas & 3.94 B & $4.01 \mathrm{C}$ & $5.10 \mathrm{~B}$ & $151 \mathrm{~A}$ & $140 \mathrm{~A}$ & $0.12 \mathrm{C}$ & $7 \mathrm{C}$ & $1.51 \mathrm{~B}$ & $8.14 \mathrm{C}$ \\
\hline Fargo & $3.09 \mathrm{C}$ & $3.18 \mathrm{D}$ & $3.47 \mathrm{C}$ & $98 \mathrm{C}$ & $76 \mathrm{C}$ & $0.24 \mathrm{~B}$ & $21 \mathrm{~B}$ & $4.25 \mathrm{~A}$ & $5.62 \mathrm{C}$ \\
\hline Grand mean & 4.04 & 5.16 & 7.30 & 131 & 98 & 0.37 & 25 & 3.62 & 50.73 \\
\hline \multicolumn{10}{|l|}{$\operatorname{LSD}(0.10)$} \\
\hline Hybrid & 0.89 & $\mathrm{~ns}$ & ns & $\mathrm{ns}$ & $\mathrm{ns}$ & $\mathrm{ns}$ & ns & ns & ns \\
\hline Location & 0.63 & 0.56 & 1.25 & 2 & 18 & 0.16 & 11 & 2.32 & 14.48 \\
\hline Hybrid-location & 0.60 & 1.09 & 1.73 & 9 & 17 & 0.20 & 14 & 1.33 & 32.06 \\
\hline
\end{tabular}

${ }^{\mathrm{x}}$ Interaction means within a column followed by the same lowercase letter and environment means followed by the same uppercase letter are not significantly different according to Fisher's protected least significant difference $(P=0.10)$; ns $=$ not significant.

${ }^{\mathrm{y}}$ Response to Beet necrotic yellow vein virus; loc. = location.

${ }^{\mathrm{z}}$ Sucrose loss $\left(\mathrm{kg} \mathrm{Mg}^{-1}\right.$ day $\left.^{-1}\right)$.

Table 2. Significance level $(P)$ of $F$ tests for comparisons of location, hybrid, and interaction means for trials conducted in $2002-03$ (Table 1), 2004 (Table 3 ), and 2005-06 (Table 4)

\begin{tabular}{|c|c|c|c|c|c|c|c|c|}
\hline \multirow[b]{2}{*}{ Trial, source ${ }^{x}$} & \multicolumn{3}{|c|}{ Respiration rate } & \multicolumn{2}{|c|}{ Extractable sucrose } & \multicolumn{2}{|c|}{ Invert sugar } & \multirow[b]{2}{*}{$\operatorname{Loss}^{2}$} \\
\hline & 30 DAH $^{\mathbf{y}}$ & 60 DAH & 120 DAH & 30 DAH & 120 DАН & 30 DAH & 120 DAH & \\
\hline \multicolumn{9}{|l|}{$2002-03$} \\
\hline Location & 0.008 & $<0.001$ & $<0.001$ & $<0.001$ & 0.001 & 0.208 & $<0.001$ & 0.004 \\
\hline Hybrid & 0.051 & 0.200 & 0.178 & 0.805 & 0.281 & 0.231 & 0.258 & 0.140 \\
\hline Location-hybrid & 0.001 & $<0.001$ & $<0.001$ & $<0.001$ & $<0.001$ & $<0.001$ & $<0.001$ & 0.002 \\
\hline \multicolumn{9}{|l|}{2004} \\
\hline Location & 0.385 & 0.577 & 0.541 & $<0.001$ & 0.008 & 0.694 & 0.496 & 0.982 \\
\hline Hybrid & 0.012 & 0.379 & 0.987 & 0.521 & 0.678 & $<0.001$ & 0.652 & 0.795 \\
\hline Location-hybrid & 0.007 & 0.005 & $<0.001$ & $<0.001$ & $<0.001$ & 0.995 & 0.024 & 0.044 \\
\hline \multicolumn{9}{|l|}{$2005-06$} \\
\hline Climax-2005, Hybrid & $<0.001$ & $<0.001$ & $<0.001$ & $<0.001$ & $<0.001$ & $\ldots$ & $<0.001$ & $<0.001$ \\
\hline NWROC-2005, Hybrid & 0.008 & 0.113 & 0.819 & 0.008 & 0.580 & & 0.152 & 0.479 \\
\hline NWROC-2006, Hybrid & 0.155 & 0.046 & 0.009 & 0.092 & 0.095 & 0.446 & 0.017 & 0.704 \\
\hline
\end{tabular}

${ }^{\mathrm{x}}$ Source of variation; NWROC $=$ Northwest Research and Outreach Center.

${ }^{\mathrm{y}} \mathrm{DAH}=$ days after harvest.

${ }^{z}$ Daily sucrose loss. 
respiration rate of roots of the rhizomaniasusceptible and -intermediate hybrids from Crookston ranged from 1.2 to 1.6 times the respiration rate of the same hybrid at Stephen. In contrast, the respiration rate of roots of the resistant hybrids from Crookston ranged from 0.41 to 0.80 times the respiration rate of roots of the same resistant hybrid from Stephen.

Roots of the two rhizomania-susceptible hybrids, ACH-820 and B-3800, from Crookston had lower extractable sucrose concentrations than roots of any of the four resistant hybrids from Crookston $30 \mathrm{DAH}$ and lower than roots of three of the four resistant hybrids 120 DAH (Table 3). There did not appear to be a similar relationship between rhizomania resistance and extractable sucrose concentration 30 or $120 \mathrm{DAH}$ in roots from Stephen. Extractable sucrose losses during 90 days in storage were less and patterns among hybrid-location combinations not as apparent in 2004 as in the 2002-03 trial (Table 1). The only indication of an association between increased invert sugar concentration and rhizomania was the high concentration $(16.72 \mathrm{~g} / 100 \mathrm{~S})$ of one rhizomaniasusceptible hybrid, ACH-820, at Crookston 120 DAH (Table 3).

The response pattern of roots from the 2005 Climax trial (Tables 2 and 4) was similar to that observed in the 2002 and 2004 trials at sites where rhizomania was present. The respiration rate of the rhizomania-susceptible hybrid ACH- 820 was higher than all other hybrids $30 \mathrm{DAH}$. At 60 and $120 \mathrm{DAH}$, both the susceptible hybrid and the hybrid with intermediate resistance, ACH-308, had higher respiration rates than the four resistant hybrids. The respiration rate of the susceptible hybrid was 1.5 times the average of the resistant hybrids $30 \mathrm{DAH}$ and 1.5 and 3.2 times that of the intermediate hybrid and the average of the resistant hybrids, respectively, $120 \mathrm{DAH}$.

Extractable sucrose concentrations at Climax 30 DAH ranged from 123 to 144 $\mathrm{kg} \mathrm{Mg}^{-1}$ and from 57 to $132 \mathrm{~kg} \mathrm{Mg}^{-1} 120$ DAH (Table 4). In all, 53\% of the extractable sucrose in roots of the susceptible hybrid from Climax 30 DAH was not available $120 \mathrm{DAH}$; a 29\% loss occurred in the intermediate hybrid and extractable sucrose losses in the resistant hybrids ranged from 6 to $8 \%$. The daily extractable sucrose loss in roots of the susceptible hybrid from Climax $\left(0.74 \mathrm{~kg} \mathrm{Mg}^{-1}\right.$ day $\left.^{-1}\right)$ was approximately six times the average extractable sucrose loss of the resistant hybrids from Climax $\left(0.12 \mathrm{~kg} \mathrm{Mg}^{-1} \mathrm{day}^{-1}\right)$. The invert sugar concentration of roots of the rhizomania-susceptible hybrid ACH820120 DAH was twice that of the intermediate hybrid ACH-308 and more than nine times the average invert sugar concentration of the four resistant hybrids.

Differences in respiration rate among hybrids were smaller and, frequently, not significant in the absence of rhizomania at NWROC in 2005 and 2006 (Table 4) compared with the differences associated with hybrids from sites with rhizomania. Respiration rate and extractable sucrose concentration $30 \mathrm{DAH}$ were the only traits influenced by hybrid in 2005 . Hybrids differed in respiration rate 30,60 , and $120 \mathrm{DAH}$

Table 3. Respiration rate 30, 60, and 120 days after harvest (DAH), and extractable sugar and invert sugar concentration of roots of rhizomania-resistant and -susceptible sugar beet hybrids 30 and 120 DAH from sites with (Crookston, MN) and without rhizomania (Stephen, MN) in 2004x

\begin{tabular}{|c|c|c|c|c|c|c|c|c|c|}
\hline \multirow[b]{2}{*}{ Hybrid, response, loc..$^{y}$} & \multicolumn{3}{|c|}{$\begin{array}{c}\text { Respiration rate } \\
\left(\mathrm{mg} \text { of } \mathrm{CO}_{2} \mathbf{k g}^{-1} \mathbf{h}^{-1}\right)\end{array}$} & \multicolumn{2}{|c|}{$\begin{array}{c}\text { Extractable sucrose } \\
\left(\mathrm{kg} \mathrm{Mg}^{-1}\right)\end{array}$} & \multicolumn{2}{|c|}{$\begin{array}{c}\text { Extractable sucrose loss } \\
30 \text { to } 120 \text { DAH }\end{array}$} & \multicolumn{2}{|c|}{$\begin{array}{c}\text { Invert sugar } \\
(\mathrm{g} / \mathbf{1 0 0} \mathrm{g} \text { of sucrose) }\end{array}$} \\
\hline & 30 DAH & 60 DAH & 120 DAH & 30 DAH & 120 DAH & Weight $^{z}$ & Percent & 30 DAH & 120 DAH \\
\hline \multicolumn{10}{|l|}{ ACH-820, susceptible } \\
\hline Crookston & $4.64 \mathrm{~b}$ & $5.36 \mathrm{ab}$ & $5.96 \mathrm{a}-\mathrm{c}$ & $121 \mathrm{~g}$ & $103 \mathrm{e}$ & $0.21 \mathrm{a}$ & $15 \mathrm{a}$ & 4.00 & $16.72 \mathrm{a}$ \\
\hline Stephen & $5.91 \mathrm{a}$ & $4.75 \mathrm{~b}-\mathrm{d}$ & $4.96 \mathrm{~b}-\mathrm{e}$ & $154 \mathrm{bc}$ & $145 \mathrm{ab}$ & $0.10 \mathrm{a}-\mathrm{c}$ & $6 \mathrm{~b}-\mathrm{d}$ & 4.71 & $5.22 \mathrm{bc}$ \\
\hline Hybrid mean & 5.28 & 5.06 & 5.46 & 137 & 124 & 0.15 & 11 & 4.36 & 10.97 \\
\hline \multicolumn{10}{|l|}{ B-3800, susceptible } \\
\hline Crookston & $4.56 \mathrm{~b}$ & $5.96 \mathrm{a}$ & $5.99 \mathrm{a}-\mathrm{c}$ & $121 \mathrm{~g}$ & $108 \mathrm{de}$ & $0.15 \mathrm{ab}$ & $11 \mathrm{bc}$ & 3.26 & $7.56 \mathrm{bc}$ \\
\hline Stephen & $4.47 \mathrm{bc}$ & $4.58 \mathrm{c}-\mathrm{e}$ & $4.85 \mathrm{~b}-\mathrm{e}$ & $161 \mathrm{ab}$ & $147 \mathrm{ab}$ & $0.16 \mathrm{ab}$ & $9 \mathrm{~b}-\mathrm{d}$ & 5.89 & $4.13 \mathrm{c}$ \\
\hline Hybrid mean & 4.51 & 5.27 & 5.42 & 141 & 127 & 0.15 & 11 & 4.57 & 5.84 \\
\hline \multicolumn{10}{|l|}{ B-4818, intermediate } \\
\hline Crookston & $4.11 \mathrm{~b}-\mathrm{d}$ & $3.85 \mathrm{ef}$ & $5.79 \mathrm{a}-\mathrm{c}$ & $124 \mathrm{fg}$ & $108 \mathrm{de}$ & $0.17 \mathrm{ab}$ & $12 \mathrm{ab}$ & 13.05 & $7.50 \mathrm{bc}$ \\
\hline Stephen & $4.50 \mathrm{bc}$ & $5.00 \mathrm{bc}$ & 3.66 ef & $155 \mathrm{a}-\mathrm{c}$ & $152 \mathrm{a}$ & $0.04 \mathrm{c}$ & $2 \mathrm{~d}$ & 14.83 & $3.38 \mathrm{c}$ \\
\hline Hybrid mean & 4.31 & 4.22 & 4.73 & 139 & 130 & 0.10 & 7 & 13.94 & 5.44 \\
\hline \multicolumn{10}{|l|}{ B-1305, resistant } \\
\hline Crookston & $3.55 \mathrm{de}$ & $4.21 \mathrm{~d}-\mathrm{f}$ & $3.26 \mathrm{ef}$ & 132 ef & $119 \mathrm{~d}$ & $0.14 \mathrm{a}-\mathrm{c}$ & $9 b-d$ & 4.08 & $3.60 \mathrm{c}$ \\
\hline Stephen & $3.97 \mathrm{c}-\mathrm{e}$ & $4.69 b-d$ & $6.61 \mathrm{ab}$ & $156 \mathrm{a}-\mathrm{c}$ & $143 \mathrm{a}-\mathrm{c}$ & $0.14 \mathrm{a}-\mathrm{c}$ & $8 b-d$ & 3.34 & $10.21 \mathrm{~b}$ \\
\hline Hybrid mean & 3.76 & 4.45 & 4.94 & 144 & 132 & 0.14 & 9 & 3.71 & 6.90 \\
\hline \multicolumn{10}{|l|}{ H-2463, resistant } \\
\hline Crookston & $3.70 \mathrm{de}$ & $3.79 \mathrm{f}$ & $2.92 \mathrm{f}$ & $141 \mathrm{~d}$ & $138 \mathrm{bc}$ & $0.03 \mathrm{c}$ & $2 \mathrm{~d}$ & 3.16 & $2.49 \mathrm{c}$ \\
\hline Stephen & $5.50 \mathrm{a}$ & $4.41 \mathrm{c}-\mathrm{e}$ & $7.14 \mathrm{a}$ & $158 \mathrm{ab}$ & $141 \mathrm{a}-\mathrm{c}$ & $0.19 \mathrm{a}$ & $10 \mathrm{bc}$ & 6.63 & $4.94 \mathrm{bc}$ \\
\hline Hybrid mean & 4.60 & 4.10 & 5.04 & 150 & 140 & 0.11 & 6 & 4.90 & 3.72 \\
\hline \multicolumn{10}{|l|}{ H-2469, resistant } \\
\hline Crookston & $3.55 \mathrm{de}$ & $3.73 \mathrm{f}$ & 3.52 ef & $137 \mathrm{de}$ & $132 \mathrm{c}$ & $0.06 \mathrm{bc}$ & $4 \mathrm{~cd}$ & 3.50 & $4.74 \mathrm{bc}$ \\
\hline Stephen & $4.32 \mathrm{bc}$ & $4.08 \mathrm{~d}-\mathrm{f}$ & $5.63 \mathrm{a}-\mathrm{d}$ & $149 \mathrm{c}$ & $142 \mathrm{a}-\mathrm{c}$ & $0.08 \mathrm{a}-\mathrm{c}$ & $5 b-d$ & 5.23 & $5.53 \mathrm{bc}$ \\
\hline Hybrid mean & 3.94 & 3.90 & 4.58 & 142 & 137 & 0.07 & 4 & 4.37 & 5.13 \\
\hline \multicolumn{10}{|l|}{ V-46177, resistant } \\
\hline Crookston & $3.47 \mathrm{e}$ & $4.34 \mathrm{c}-\mathrm{f}$ & $3.79 \mathrm{~d}-\mathrm{f}$ & $138 \mathrm{de}$ & $133 \mathrm{c}$ & $0.06 \mathrm{bc}$ & $4 \mathrm{~cd}$ & 2.91 & $4.19 \mathrm{c}$ \\
\hline Stephen & $4.40 \mathrm{bc}$ & $4.82 \mathrm{bc}$ & $4.73 \mathrm{c}-\mathrm{f}$ & $162 \mathrm{a}$ & $152 \mathrm{a}$ & $0.11 \mathrm{a}-\mathrm{c}$ & $6 b-d$ & 3.79 & $3.91 \mathrm{c}$ \\
\hline Hybrid mean & 3.94 & 4.58 & 4.26 & 150 & 142 & 0.08 & 5 & 3.35 & 4.05 \\
\hline \multicolumn{10}{|l|}{ Location means } \\
\hline Crookston & 4.73 & 4.46 & 4.46 & 130 & 120 & 0.12 & 8 & 4.85 & 6.69 \\
\hline Stephen & 3.94 & 4.62 & 5.37 & 156 & 146 & 0.12 & 6 & 6.35 & 5.33 \\
\hline Grand mean & 4.33 & 4.54 & 4.92 & 144 & 133 & 0.12 & 7 & 5.60 & 6.01 \\
\hline \multicolumn{10}{|l|}{$\operatorname{LSD}(0.10)$} \\
\hline Hybrid & ns & ns & ns & ns & ns & ns & ns & 1.88 & ns \\
\hline Location & ns & ns & ns & 2 & 7 & ns & $\mathrm{ns}$ & ns & ns \\
\hline Hybrid-location & 0.58 & 0.77 & 1.84 & 7 & 11 & 0.12 & 7 & ns & 5.98 \\
\hline
\end{tabular}

${ }^{\mathrm{x}}$ Interaction means within a column followed by the same letter are not significantly different according to Fisher's protected least significant difference $(P=$ $0.10) ; \mathrm{ns}=$ not significant.

y Response to Beet necrotic yellow vein virus; loc. = location.

${ }^{z}$ Sucrose loss $\left(\mathrm{kg} \mathrm{Mg}^{-1}\right.$ day $\left.^{-1}\right)$. 
and extractable sucrose concentration 30 and $120 \mathrm{DAH}$ in 2006. Of more importance to the objectives of this research was the absence of an apparent association between the resistance of a cultivar to rhizomania and respiration rate or sucrose loss in the absence of rhizomania. Even when differences among hybrids were significant, the difference between the rhizomania-susceptible or -intermediate hybrid and some of the resistant hybrids was not significant.

In summary, roots of susceptible hybrids from the four sites with rhizomania had respiration rates $30 \mathrm{DAH}$ that ranged from 0.68 to $2.79 \mathrm{mg}$ of $\mathrm{CO}_{2} \mathrm{~kg}^{-1} \mathrm{~h}^{-1}$ higher than the average for roots of the resistant hybrids from the same site (Table 5). This difference ranged from 2.60 to $13.88 \mathrm{mg}$ of $\mathrm{CO}_{2} \mathrm{~kg}^{-1} \mathrm{~h}^{-1} 120$ DAH. In contrast, differences in respiration rates between resistant and susceptible hybrids in the absence of rhizomania were small, sometimes positive, and, for some environments, not significant.

Roots of resistant hybrids from sites with rhizomania had an average of $18 \mathrm{~kg}$ more extractable sucrose per ton than roots from susceptible hybrids $30 \mathrm{DAH}$, and this difference increased to $55 \mathrm{~kg} \mathrm{Mg}^{-1} 120$ DAH (Table 5). In the absence of rhizomania, differences in extractable sucrose concentration between the susceptible and resistant hybrids were small, with no consistent advantage for either group. Daily extractable sucrose losses of roots of susceptible hybrids from sites with rhizomania were from 0.11 to $0.72 \mathrm{~kg} \mathrm{Mg}^{-1}$ day $^{-1}$ higher than losses from resistant hybrids. The average difference between resistant and susceptible hybrids in daily sucrose loss for sites with rhizomania was $0.42 \mathrm{~kg}$ $\mathrm{Mg}^{-1}$ day $^{-1}$; for sites without rhizomania, the average difference was $0.08 \mathrm{~kg} \mathrm{Mg}^{-1}$ day $^{-1}$. Optically active compounds that affect sucrose measurements based upon polarimetry, especially invert sugars, are formed as roots deteriorate (3); therefore, it is feasible that the sucrose losses reported here underestimate the actual sucrose loss.

The invert sugar concentration of roots of the susceptible hybrid from Eldred, a site with rhizomania, had substantially higher invert sugar concentration than roots of the resistant hybrid from that site 30 DAH (Table 5). Corresponding differences at other sites were smaller, with little or no indication that relative invert sugar concentration $30 \mathrm{DAH}$ was related to the rhizomania resistance of the hybrid. However, at $120 \mathrm{DAH}$, the invert sugar concentration of roots of susceptible hybrids from sites with rhizomania ranged from 8.38 to $286.72 \mathrm{~g} / 100 \mathrm{~S}$ higher than that for resistant hybrids from the same site. There was no apparent relationship between rhizomania resistance and relative invert sugar concentration $120 \mathrm{DAH}$ at sites without rhizomania.

\section{DISCUSSION}

When assessing the impact of a disease, it is desirable to have sites where the disease of interest is uniformly distributed across the field and other diseases and pests have little or no affect on the traits of interest and, for comparison, to have fields where diseases are of little importance or are effectively controlled. Meeting these requirements made it difficult to examine a common set of hybrids for all site and year combinations. Yield trials designed specifically to evaluate the relative performance of rhizomania-resistant and -susceptible hybrids either were complicated by the presence of other root diseases or rhizomania did not develop. Consequently, roots from trials established for other purposes were evaluated with some compromises in number and uniformity of hybrids available and experimental design. The $10 \%$ significance level was chosen over the frequently used 5 and $1 \%$ levels to reduce the probability of committing a type II error (6). In this study, the economic consequences of declaring two hybrids equal when, in fact, they are different (a type II error) are greater than conclud-

Table 4. Respiration rate 30, 60, and 120 days after harvest (DAH) and extractable sucrose and invert sugar concentration of roots of rhizomania-resistant and -susceptible sugar beet hybrids 30 and 120 DAH from sites with (Climax, MN, 2005) and without (Northwest Research and Outreach Center [NWROC], 2005-06) rhizomania ${ }^{x}$

\begin{tabular}{|c|c|c|c|c|c|c|c|c|c|c|}
\hline \multirow[b]{2}{*}{ Location, hybrid } & \multirow[b]{2}{*}{ Response $^{y}$} & \multicolumn{3}{|c|}{$\begin{array}{c}\text { Respiration rate } \\
\left(\mathrm{mg} \text { of } \mathrm{CO}_{2} \mathbf{k g}^{-1} \mathbf{h}^{-1}\right)\end{array}$} & \multicolumn{2}{|c|}{$\begin{array}{c}\text { Extractable sucrose } \\
\left(\mathrm{kg} \mathrm{Mg}^{-1}\right)\end{array}$} & \multicolumn{2}{|c|}{$\begin{array}{l}\text { Extractable sucrose } \\
\text { loss (30 to } 120 \text { DAH) }\end{array}$} & \multicolumn{2}{|c|}{$\begin{array}{c}\text { Invert sugar } \\
\text { (g/100 g of sucrose) }\end{array}$} \\
\hline & & 30 DAH & 60 DAH & 120 DAH & 30 DAH & 120 DAH & Weight $^{z}$ & Percent & 30 DAH & 120 DAH \\
\hline \multicolumn{11}{|l|}{ Climax 2005} \\
\hline ACH-820 & Susceptible & $8.17 \mathrm{a}$ & $8.44 \mathrm{a}$ & $20.19 \mathrm{a}$ & $123 \mathrm{~d}$ & $57 \mathrm{c}$ & $0.74 \mathrm{a}$ & $53 \mathrm{a}$ & $\ldots$ & $37.50 \mathrm{a}$ \\
\hline ACH-308 & Intermediate & $5.92 \mathrm{~b}$ & $7.69 \mathrm{a}$ & $13.70 \mathrm{~b}$ & $133 \mathrm{c}$ & $93 \mathrm{~b}$ & $0.44 \mathrm{~b}$ & $29 \mathrm{~b}$ & $\ldots$ & $18.02 \mathrm{~b}$ \\
\hline B-1305 & Resistant & $4.94 \mathrm{c}$ & $4.89 \mathrm{c}$ & $5.82 \mathrm{c}$ & $138 \mathrm{~b}$ & $127 \mathrm{a}$ & $0.13 \mathrm{c}$ & $8 \mathrm{c}$ & $\ldots$ & $3.75 \mathrm{c}$ \\
\hline H-2467 & Resistant & $5.31 \mathrm{bc}$ & $5.82 \mathrm{~b}$ & $7.73 \mathrm{c}$ & $144 \mathrm{a}$ & $131 \mathrm{a}$ & $0.14 \mathrm{c}$ & $8 \mathrm{c}$ & $\ldots$ & $5.21 \mathrm{c}$ \\
\hline HH-317 & Resistant & $5.60 \mathrm{c}$ & $5.18 \mathrm{bc}$ & $6.26 \mathrm{c}$ & $142 \mathrm{ab}$ & $132 \mathrm{a}$ & $0.11 \mathrm{c}$ & $6 \mathrm{c}$ & $\ldots$ & $3.67 \mathrm{c}$ \\
\hline Prizm & Resistant & $5.67 \mathrm{~b}$ & $4.90 \mathrm{c}$ & $5.44 \mathrm{c}$ & $138 \mathrm{~b}$ & $127 \mathrm{a}$ & $0.13 \mathrm{c}$ & $8 \mathrm{c}$ & $\ldots$ & $3.34 \mathrm{c}$ \\
\hline Location mean & $\ldots$ & 5.93 & 6.16 & 9.86 & 136 & 111 & 0.27 & 19 & $\ldots$ & 11.91 \\
\hline \multicolumn{11}{|l|}{ NWROC 2005} \\
\hline ACH-820 & Susceptible & $5.57 \mathrm{bc}$ & $6.13 \mathrm{a}$ & 7.99 a & $148 \mathrm{~cd}$ & $124 \mathrm{a}$ & $0.27 \mathrm{a}$ & $17 \mathrm{a}$ & $\ldots$ & $7.58 \mathrm{a}$ \\
\hline $\mathrm{ACH}-308$ & Intermediate & $7.04 \mathrm{a}$ & $8.05 \mathrm{a}$ & $13.00 \mathrm{a}$ & $154 \mathrm{bc}$ & $128 \mathrm{a}$ & $0.29 \mathrm{a}$ & $16 \mathrm{a}$ & $\ldots$ & $9.44 \mathrm{a}$ \\
\hline B-4818 & Intermediate & $5.81 \mathrm{bc}$ & $6.51 \mathrm{a}$ & $9.97 \mathrm{a}$ & $158 \mathrm{ab}$ & $144 \mathrm{a}$ & $0.15 \mathrm{a}$ & $8 \mathrm{a}$ & $\ldots$ & $6.58 \mathrm{a}$ \\
\hline B-1305 & Resistant & $5.16 \mathrm{~b}-\mathrm{d}$ & $5.70 \mathrm{a}$ & $9.07 \mathrm{a}$ & $151 \mathrm{bc}$ & $132 \mathrm{a}$ & $0.22 \mathrm{a}$ & $13 \mathrm{a}$ & $\ldots$ & $8.14 \mathrm{a}$ \\
\hline H-2463 & Resistant & $5.03 \mathrm{~cd}$ & $5.05 \mathrm{a}$ & $8.66 \mathrm{a}$ & $157 \mathrm{a}-\mathrm{c}$ & $136 \mathrm{a}$ & $0.24 \mathrm{a}$ & $13 \mathrm{a}$ & $\ldots$ & $5.87 \mathrm{a}$ \\
\hline H-2469 & Resistant & $5.89 \mathrm{~b}$ & $6.86 \mathrm{a}$ & $9.39 \mathrm{a}$ & $142 \mathrm{~d}$ & $129 \mathrm{a}$ & $0.15 \mathrm{a}$ & $9 \mathrm{a}$ & $\ldots$ & $5.66 \mathrm{a}$ \\
\hline НH-317 & Resistant & $4.52 \mathrm{~d}$ & $6.20 \mathrm{a}$ & $9.06 \mathrm{a}$ & $163 \mathrm{a}$ & $140 \mathrm{a}$ & $0.26 \mathrm{a}$ & $14 \mathrm{a}$ & $\ldots$ & $5.91 \mathrm{a}$ \\
\hline Prizm & Resistant & $5.61 \mathrm{bc}$ & $6.01 \mathrm{a}$ & $9.45 \mathrm{a}$ & $159 \mathrm{ab}$ & $144 \mathrm{a}$ & $0.17 \mathrm{a}$ & $10 \mathrm{a}$ & $\ldots$ & $8.50 \mathrm{a}$ \\
\hline VDH-46177 & Resistant & $5.98 \mathrm{~b}$ & $7.78 \mathrm{a}$ & $10.17 \mathrm{a}$ & $164 \mathrm{a}$ & $124 \mathrm{a}$ & $0.44 \mathrm{a}$ & $24 \mathrm{a}$ & $\ldots$ & $14.52 \mathrm{a}$ \\
\hline Location mean & $\ldots$ & 5.62 & 6.48 & 9.64 & 155 & 133 & 0.24 & 14 & $\ldots$ & 8.02 \\
\hline \multicolumn{11}{|l|}{ NWROC 2006} \\
\hline ACH-820 & Susceptible & $4.51 \mathrm{a}$ & $3.92 \mathrm{a}-\mathrm{c}$ & $4.13 \mathrm{c}$ & $176 \mathrm{a}$ & $172 \mathrm{a}$ & $0.04 \mathrm{a}$ & $2 \mathrm{a}$ & $4.41 \mathrm{a}$ & $1.58 \mathrm{~b}$ \\
\hline ACH-308 & Intermediate & $4.37 \mathrm{ab}$ & $4.30 \mathrm{a}$ & $4.38 \mathrm{bc}$ & $164 b$ & $158 \mathrm{a}-\mathrm{c}$ & $0.07 \mathrm{a}$ & $4 \mathrm{a}$ & $3.17 \mathrm{a}$ & $2.90 \mathrm{~b}$ \\
\hline B-1305 & Resistant & $3.78 \mathrm{c}$ & $3.83 \mathrm{bc}$ & $5.25 \mathrm{~b}$ & $159 \mathrm{~b}$ & $150 \mathrm{bc}$ & $0.10 \mathrm{a}$ & $5 \mathrm{a}$ & $2.75 \mathrm{a}$ & $3.06 \mathrm{~b}$ \\
\hline H-2463 & Resistant & $4.02 \mathrm{a}-\mathrm{c}$ & $4.20 \mathrm{ab}$ & $6.76 \mathrm{a}$ & $158 \mathrm{~b}$ & $143 \mathrm{c}$ & $0.16 \mathrm{a}$ & $9 \mathrm{a}$ & $3.71 \mathrm{a}$ & $5.20 \mathrm{a}$ \\
\hline H-2469 & Resistant & $4.06 \mathrm{a}-\mathrm{c}$ & $3.72 \mathrm{c}$ & $4.32 \mathrm{bc}$ & $164 \mathrm{~b}$ & $15 \mathrm{bc}$ & $0.10 \mathrm{a}$ & $6 \mathrm{a}$ & $3.44 \mathrm{a}$ & $2.70 \mathrm{~b}$ \\
\hline НH-317 & Resistant & $3.62 \mathrm{c}$ & $3.53 \mathrm{c}$ & $3.88 \mathrm{c}$ & $165 \mathrm{~b}$ & $158 \mathrm{a}-\mathrm{c}$ & $0.07 \mathrm{a}$ & $4 \mathrm{a}$ & $3.90 \mathrm{a}$ & $3.04 \mathrm{~b}$ \\
\hline Prizm & Resistant & $3.89 \mathrm{bc}$ & $4.30 \mathrm{a}$ & $4.91 \mathrm{bc}$ & $164 \mathrm{~b}$ & $159 \mathrm{ab}$ & $0.06 \mathrm{a}$ & $3 \mathrm{a}$ & $3.21 \mathrm{a}$ & $2.59 \mathrm{~b}$ \\
\hline Location mean & $\ldots$ & 4.04 & 3.97 & 4.81 & 164 & 156 & 0.09 & 5 & 3.51 & 3.14 \\
\hline
\end{tabular}

${ }^{\mathrm{x}}$ Differences among means within a column and location followed by the same letter are not significant according to Fisher's protected least significant difference $(P=0.10)$.

${ }^{y}$ Response to Beet necrotic yellow vein virus.

${ }^{\text {z }}$ Sucrose loss $\left(\mathrm{kg} \mathrm{Mg}^{-1} \mathrm{day}^{-1}\right)$. 
Table 5. Difference between average of rhizomania-resistant and -susceptible sugar beet hybrids for respiration rate 30,60 , and 120 days after harvest (DAH) and extractable sucrose and invert sugar concentration 30 and 120 DAH in four locations with rhizomania and five locations without rhizomania ${ }^{\mathrm{x}}$

\begin{tabular}{|c|c|c|c|c|c|c|c|c|c|}
\hline \multirow[b]{2}{*}{ Rhizomania, location $^{y}$} & \multirow[b]{2}{*}{ Year } & \multicolumn{3}{|c|}{$\begin{array}{c}\text { Respiration rate } \\
\left(\mathbf{m g} \text { of } \mathbf{C O}_{2} \mathbf{k g}^{-1} \mathbf{h}^{-1}\right)\end{array}$} & \multicolumn{2}{|c|}{$\begin{array}{c}\text { Extractable sucrose } \\
\left(\mathrm{kg} \mathrm{Mg}^{-1}\right)\end{array}$} & \multirow[b]{2}{*}{$\operatorname{Loss}^{\mathbf{z}}$} & \multicolumn{2}{|c|}{$\begin{array}{c}\text { Invert sugar } \\
\text { (g/100 } \mathrm{g} \text { of sucrose) }\end{array}$} \\
\hline & & 30 DAH & 60 DAH & 120 DAH & 30 DAH & 120 DAH & & 30 DAH & 120 DAH \\
\hline \multicolumn{10}{|l|}{ Present } \\
\hline Eldred & 2002 & $-2.29 * *$ & $-8.21 * *$ & $-11.52 * *$ & $26 * *$ & $90 * *$ & $-0.72 * *$ & $-5.49 * *$ & $-286.72 * *$ \\
\hline Crookston & 2002 & -0.68 & $-1.76 * *$ & $-3.57 * *$ & $12 * *$ & $34 * *$ & $-0.24 *$ & -0.75 & $-64.99 * *$ \\
\hline Crookston & 2004 & $-1.03 * *$ & $-1.64 * *$ & $-2.60 * *$ & $16 * *$ & $25 * *$ & $-0.11 * *$ & -0.21 & $-8.38 * *$ \\
\hline Climax & 2005 & $-2.79 * *$ & $-3.42 * *$ & $-13.88 * *$ & $17 * *$ & $72 * *$ & $-0.61 * *$ & & $-33.50 * *$ \\
\hline Mean & $\ldots$ & -1.69 & -3.71 & -7.89 & 18 & 55 & -0.42 & -2.15 & -98.40 \\
\hline \multicolumn{10}{|l|}{ Absent } \\
\hline St. Thomas & 2003 & -0.02 & -0.38 & -0.82 & $20 * *$ & -6 & $-0.16 *$ & -0.05 & -5.16 \\
\hline Fargo & 2003 & $-1.02 * *$ & $-0.55 *$ & -0.59 & -2 & -7 & 0.05 & -0.55 & -2.17 \\
\hline Stephen & 2004 & $-0.64 * *$ & -0.17 & 1.12 & -2 & -2 & 0.00 & -0.55 & 1.47 \\
\hline NWROC & 2005 & -0.19 & 0.13 & 1.31 & $8 *$ & 10 & -0.03 & $\ldots$ & 0.52 \\
\hline NWROC & 2006 & $-0.63 * *$ & 0.00 & $0.89 *$ & $-28 * *$ & $-19 * *$ & 0.06 & -1.01 & 0.81 \\
\hline Mean & $\ldots$ & -0.50 & -0.19 & 0.39 & -9 & -5 & -0.08 & -0.54 & -0.91 \\
\hline
\end{tabular}

${ }^{x}$ Asterisks (* and **) indicate that the difference (average of resistant hybrids - average of susceptible hybrids) is significantly different from 0 (based upon a two-tailed $t$ test) at the 0.10 and 0.05 significance level, respectively.

${ }^{y}$ NWROC $=$ Northwest Research and Outreach Center.

${ }^{\mathrm{z}}$ Sucrose loss $\left(\mathrm{kg} \mathrm{Mg}^{-1} \mathrm{day}^{-1}\right)$.

ing that two hybrids are different when they are actually equal (a type I error with probability equal to the significance level). Increasing the protection against a type I error $(\alpha)$ increases the probability of committing a type II error.

The relative performance of hybrids at any one site may be affected by many factors (3-5), including the presence or absence of rhizomania. However, an overall examination of the results from all sites indicated that rhizomania substantially increased postharvest storage respiration rate, sucrose loss, and invert sugar accumulation in susceptible hybrids and production of rhizomania-resistant hybrids minimized these losses. The respiration rate and invert sugar concentrations of susceptible hybrids from areas with rhizomania frequently were slightly elevated 30 DAH and appeared to increase at an accelerated rate during storage compared with susceptible hybrids from areas without rhizomania and resistant hybrids from all areas. The elevated respiration rates not only imply an increase in sucrose loss but also may cause an increase in pile temperature, which increases respiration rate further and facilitates the development of storage rots (3). The pattern for respiration rate and invert sugar accumulation observed in this study and a similar response pattern for invert sugar observed by Hein et al. (11) indicate that the postharvest sucrose losses and processing inefficiencies associated with diseased roots can be minimized by processing roots from fields or localities with rhizomania soon after harvest. Long-term storage of diseased roots should be avoided. The magnitude of the environment-to-environment differences among the four sites with rhizomania (Table 5) cannot be explained by differences in apparent severity; suggesting that estimates of future postharvest losses due to rhizomania will be imprecise.
As a result of improvements in yield potential and quality of rhizomaina-resistant hybrids adapted to the region and the continued spread of rhizomania, growers' acceptance of resistant hybrids has increased and interest in hybrids with intermediate resistance has decreased. To a large extent, the widespread use of rhizomania-resistant hybrids should alleviate the storage losses associated with diseased roots, at least for a while. However, strains of the virus have been characterized and there is evidence that a strain capable of overcoming the major resistance gene, $R z_{l}$, in most, if not all, of the current regionally adapted hybrids is present in California and maybe elsewhere (15). If this virulent strain were to become established in the upper Midwest, processors may again be faced with a large volume of diseased roots in storage piles. Until there is information indicating otherwise, it seems reasonable to assume that any new strain that produces symptoms and severity similar to that observed in the susceptible hybrids in these trials would behave similarly in storage to the diseased roots in these trials.

\section{ACKNOWLEDGMENTS}

We thank N. Jonason, J. Thompson, J. Eide, T. Cymbaluk, and J. Nielsen for technical assistance; and American Crystal Sugar Co. agriculturalists N. Boeddeker, C. Funk, K. Johnson, and A. Cattanach for identifying suitable sites and assistance in obtaining the samples.

\section{LITERATURE CITED}

1. Bugbee, W. M. 1979. The effect of plant age, storage, moisture, and genotype on storage rot evaluation of sugarbeet. Phytopathology 69:414-416.

2. Campbell, L. G. 2005. Postharvest storage traits. Pages 122-126 in: Genetics and Breeding of Sugar Beet. E. Biancardi, L. G. Campbell, G. N. Skaracis, and M. DeBiaggi, eds. Science Publishers, Enfield, NH.

3. Campbell, L. G., and Klotz, K. L. 2006. Storage. Pages 387-408 in: Sugar Beet. P. Draycott, ed. Blackwell Publishing, London.
4. Campbell, L. G., and Klotz, K. L. 2006. Post harvest storage losses associated with Aphanomyces root rot in sugarbeet. J. Sugar Beet Res. 43:113-127.

5. Campbell, L. G., and Klotz, K. L. 2007. Characterizing sugarbeet varieties for postharvest storage losses complicated by environment and genotype $\mathrm{X}$ environment interactions. Can. J. Plant Sci. 87: 121-127.

6. Carmer, S. G. 1976. Optimum significance levels for application of the least significant difference in crop performance trials. Crop Sci. 16:95-99.

7. De Biaggi, M. 2005. Rhizomania. Pages 80-85 in: Genetics and Breeding of Sugar Beet. E. Biancardi, L. G. Campbell, G. N. Skaracis, and M. De Baiggi, eds. Science Publishers, Inc., Enfield, NH.

8. Dexter, S. T., Frakes, M. G., and Snyder, F. W. 1967. A rapid and practical method of determining extractable white sugar as may be applied to the evaluation of agronomic practices and grower deliveries in the sugar beet industry. J. Am. Soc. Sugar Beet Technol. 14:433454.

9. Duffus, J. E. 1986. Rhizomania. Pages 29-30 in: Compendium of Beet Diseases and Insects. E. D. Whitney and J. E. Duffus, eds. American Phytopathological Society Press, St. Paul, MN.

10. Dutton, J., and Huijbregts, T. 2006. Root quality and processing. Pages $409-442$ in: Sugar Beet. P. Draycott, ed. Blackwell Publishing, London.

11. Hein, W., Pollach, G., and Harzl, E. 2004. Investigations on the storage behavior of rhizomania tolerant sugar beet varieties. Zuckerindustrie 129:161-173.

12. Littell, R. C., Stroup, W. W., and Freund, R. J. 2002. SAS for Linear Models, 4th ed. SAS Institute Inc., Cary, NC.

13. MacIntosh, M. S. 1983. Analysis of combined experiments. Agron. J. 75: 153-155.

14. McGinnis, R. A. 1982. Analysis of sucrose content. Pages 67-76 in: Beet Sugar Technology, 3rd ed. R. A. McGinnis, ed. Beet Sugar Development Foundation, Denver.

15. Rush, C. M., Liu, H.-Y., Lewellen, R. T., and Acosta-Leal, R. 2006. The continuing saga of rhizomania of sugar beets in the United States. Plant Dis. 90:4-15.

16. Smith, G. A., and Ruppel, E. G. 1971. Cercospora leaf spot as a predisposing factor in storage rot of sugar beet roots. Phytopathology 61:1485-1487. 